\title{
Microangiopathy in the Digestive Tract in Subjects with Diabetes of Early Onset and Long Duration*
}

\author{
L. ATgervalL and J. SÄvE-SöDERBERGH \\ Pathological Institute and Sahlgrenska Sjukhuset, University of Göteborg, Sweden \\ Received February 22, 1966
}

\begin{abstract}
Summary. The digestive tract has been examined by light microscopy in 17 subjects with diabetes of early onset, long duration and with various causes of death, in 6 "normal" controls and 10 controls with uremia and/ or hypertension. In the diabetics grave lesions were demonstrated to a large extent in the capillaries and venules of the oral mucosa, and in small arteries and arterioles in the gastrointestinal tract (from the oesophagus to rectum.). The capillary and venular lesions were similar to those earlier described in the skin of diabetics. The arterial lesion was characterized by a hyalin, strongly PAS. positive, picrinophilic (eosinophilic), richly fat-containing (sudanophilic) wall thickening accompanied by heavy reduction of the lumen, endothelial atrophy and medial degeneration. Similar arterial lesions were demonstrated in the kidneys, pancreas, liver, spleen, adrenal glands, testes, prostate and ovaries. The study suggests that hypertension was not of essential importance to the development of the arterial lesions. It is assumed that the grave arterial lesion accentuates terminally in the course of diabetes, where final complications such as ischemia and adrenocortical overactivity are of pathogenetic significance.
\end{abstract}

Micro-angiopathie dans l'appareil digestif de sujets atteints de diabète précoce et de longue durée.

Résumé. On a examiné au microscope optique l'appareil digestif de 17 sujets atteints de diabète précoce, de longue durée et dont la mort était due à différentes causes, de 6 sujets de contrôle "normaux» et de 10 autres patients atteints d'urémie et/ou d'hypertension. Chez les diabétiques on a trouvé, dans une grande mesure, de graves lésions localisées dans les capillaires et les veinules de la muqueuse buccale, et dans les petites artères et artérioles de l'appareil gastro-intestinal (de l'oesophage au rectum). Les lésions des capillaires et des veinules étaient semblables à celles précédemment décrites dans la peau des diabétiques. La lésion artérielle était caractérisée par un épaissement de la paroi, hyalin, fortement PAS-positif, picrinophile (éosinophile), contenant beaucoup de graisse (soudanophile), accompagné d'une forte róduction de la lumière, d'une atrophie endothéliale, et d'une dégénérescence de la média. Dos lésions artérielles semblables ont été trouvées dans les reins, le pancréas, le foie, la rate, les glandes surrénales, les testicules, la prostate et les ovaires. Cette étude suggère que l'hypertension n'était pas d'importance essentielle pour le déve. loppement des lésions artérielles. On admet que la lésion artérielle grave s'accentue vers le stade final du diabète, où des complications finales, telles que l'ischémie et la suractivité adrénocorticale, sont d'importance pathogénique.

Mikroangiopathie des Verdauungstraktes bei Patienten mit frühmanifestem Langzeit-Diabetes.

Zusammenfassung Bei 17 Patienten mit frühmanifestem Langzeit-Diabetes mit verschiedener Todesursache bei 6 ,normalen" Kontrollpersonen und 10 Kontrollpersonen mit Uraemie und/oder Bluthochdruck wurde der Verdauungstrakt lichtmikroskopisch untersucht. Bei den Diabetikern wurden an den Kapillaren und Venolen der Mundschleimhaut in großer Ausdehnung schwere Veränderungen gefunden, ebenso in den kleinen Arterien und Arteriolen des Verdauungstraktes (vom Oesophagus bis zum Rectum). Die Veränderungen an den Kapillaren und Venolen waren ähnlich wie die schon früher in der Haut von Diabetikern beschriebenen. Der arterielle Schaden war durch eine hyaline, stark PAS-positive, picrinophile (eosinophile), reichlich fettenthaltende (sudanophile) Wandverdickung charakterisiert, die mit einer starken Einengung des Lumens, Endothelatrophie und Mediadegeneration einherging. Ähnliche arterielle Veränderungen wurden an den Nieren, an Pankreas, Leber, Milz, Nebennieren, Testes, Prostata und Ovarien nachgewiesen. Die Untersuchung läßt vermuten, daß der Bluthochdruck für die Entwicklung der arteriellen Schäden nicht von wesentlicher Bedeutung war. Es wird angenommen, daß die schweren arteriellen Veränderungen im Endstadium des Diabetes besonders ausgeprägt werden, wo Spätkomplikationen wie Durchblutungsstörungen und Überaktivität der Nebenniere von pathogenetischer Bedeutung sind.
Diabetic microangiopathy comprises the characteristic, though not pathognomic (nodular glomerulosclerosis possibly excepted) changes in the peripheral vascular bed of diabetics. Recent investigations suggest that diabetic microangiopathy is not limited to organs such as the kidneys and eyes but is rather a generalized process. Changes have been found in capillaries and venules as well as in arterioles and small arteries up to the size of the digital arteries. There is good agreement among most authors that the capillary changes

* Presented in part at the Annual Meeting of the Swedish Medical Society, Stockholm 1964 (ANGERvaLL and SÄVE-SöDERBERGH, 1965). take the form of wall thickening, reduction of the lumen and, usually, increased PAS reactivity, interpreted as evidence of increased deposition in the vascular walls of neutral mucopolysaccharides. Such capillary changes are best documented in skin (AAGENaES and Moe, 1961; Handelsmax et al., 1962; Angervall and Fagerberg, 1962; Baxson and Lacy, 1964; PederSEN and OLSEX, 1962; WEBER and WICHT, 1962; BOJSEN-Møller etal., 1963; Funk, 1965; Moore and Frew, 1965; PIERI et al., 1965) and have also been demonstrated in striated muscle (Holle, 1960; Z Bloodworti, 1963; Fuchs, 1964; ANgervall and Stener, 1965; Bencosine et al., 1966). Some authors have reported capillary endothelial proliferation, es- 
pecially in conjunction with endothelial proliferation in arterioles and small arteries (GoLdenBERG et al., 1959; Handelsmax et al., 1962; Pedersen and OLSEN, 1962; MoORE and Frew, 1965), although other authors have been unable to verify this (WEBER and WICHT, 1962 ; BLOODWORTH, 1963; BANSON and LACY, 1964; SÄVE-SÖDERBERGH et al., 1965).

Advanced arteriolar changes manifested by hyalin thickening and fat deposition in the vascular walls have been demonstrated in the liver (DaGNinI and MoreSCHI, 1959; ZSCHOCH, 1963) and pancreas (LaZARUS and VoLK, 1961). Peripheral nerves have been shown to be the site of hyalin thickening of arteriolar walls (Woltuan and Wilder, 1929; Fagerberg, 1959). In a series of tissues - including skin, muscle, nerves, myocardium, placenta and brain - endothelial proliferation with deposition of PAS-positive fibrils has been reported in arterioles and small arteries, and was considered to be specific to diabetes (BURSTEIN et al., 1957; Goldenberg et al., 1959; Blumenthal et al., 1960; Auex et al., 1962; Pedersen and Olsenv, 1962); but other authors have been unable to verify these findings and have questioned their specificity (Lw CoMPTE, 1964; FUNK, 1965).

\section{Material and Methods}

Samples from various parts of the digestive tract were taken at autopsy on 4 women and 13 men with diabetes of early onset who died at an average age of 38 years. Data on age, duration of diabetes (average 23 years), blood pressure and cause of death are given in Table 1. Most subjects had hypertension during their last year of life. The serum cholesterol was definitely elevated $(450 \mathrm{mg} \%$ ) in Case 6 . All the diabetics had received insulin treatment and displayed clinical signs of nephropathy and (except for Case 17) retinopathy, and most of them of neuropathy as well.

Clinical data and causes of death for control groups I and II are given in Table 2. Control group I comprised similar digestive tract preparations from random cases in our autopsy population, the age distribution of these cases corresponded to that of the diabetics. Control group II included similar preparations from specially selected cases with prolonged hypertension and chronic renal disease in whom the cause of death was uraemia, the object being to estimate the effect of hypertension and uraemia on the development of vascular lesions in the digestive tract.

Table 1. Sex, age, duration of diabetes, blood pressure, weight of the heart and causes of death in the diabetics

\begin{tabular}{rllllll}
\hline No. & Sex & Age & $\begin{array}{l}\text { Dur- } \\
\text { ation }\end{array}$ & $\begin{array}{l}\text { Blood } \\
\text { pressure }\end{array}$ & $\begin{array}{l}\text { Weight of } \\
\text { the heart } \\
\text { (gm) }\end{array}$ & Causes of death \\
\hline 1 & F & 23 & 22 & $180 / 110$ & 230 & Suburaemia, bronchopneumoniae \\
2 & F & 32 & 25 & $215 / 120$ & 310 & Uraemia \\
3 & F & 38 & 19 & $250 / 130$ & 400 & Uraemia \\
4 & F & 41 & 14 & $180 / 100$ & 350 & Acute pyelonephritis, uraemia \\
5 & M & 28 & 27 & $190 / 110$ & 390 & Uraemia \\
6 & M & 28 & 21 & $200 / 110$ & 555 & Myocardial infarction, uraemia \\
7 & M & 28 & 20 & $140 / 110$ & 430 & Myocardial infarction \\
8 & M & 31 & 22 & $185 / 120$ & 460 & Uraemia \\
9 & Mraemia \\
10 & M & 33 & 15 & $210 / 115$ & 490 & Uraemia \\
11 & M & 35 & $\mathbf{1 8}$ & $210 / 120$ & 570 & Acute pyelonephritis, uraemia \\
12 & M & 42 & 24 & $200 / 110$ & 370 & Uraemia \\
13 & M & 45 & 21 & $205 / 115$ & 550 & Uraemia \\
14 & M & 47 & 36 & $190 / 120$ & 450 & Myocardial infarction \\
15 & M & 51 & 36 & $180 / 90$ & 620 & Uraemia \\
16 & M & 54 & 14 & $285 / 120$ & 550 & Myocardial infarction \\
17 & M & 63 & 44 & $140 / 80$ & 610 &
\end{tabular}

Diabetic microangiopathy in the digestive tract has previously been observed in biopsy specimens and resected portions of the stomach (ANGERVALL et al., 1961, 1962).

The present publication will describe the histopathology and discuss the pathogenesis of vascular changes in the oral mucosa, oesophagus, stomach, small and large bowel and rectum, as observed in sub. jects with diabetes of early onset and long duration and with various causes of death.
The samples to be used for histological examination were fixed in 10 per cent neutral formalin solution, dehydrated and paraffin embedded in the usual manner. Consecutive $5 \mu$ sections were stained according to van Gieson and with McManus's PAS and Weigert's elastin stains. Frozen sections were stained for fat with Scharlach R. The vascular wall thickness of capillaries and venules in oral mucosa and of arterioles elsewhere in the digestive tract was graded from + to +++++ according to a subjective scale. 
Table 2. Sex, age, blood pressure, weight of the heart and diagnosis of the controls $I$ and II

\begin{tabular}{|c|c|c|c|c|c|c|c|c|c|c|c|}
\hline \multicolumn{6}{|c|}{ Controls I } & \multicolumn{6}{|c|}{ Controls II } \\
\hline No. & Sex & Age & $\begin{array}{l}\text { Blood } \\
\text { pressure }\end{array}$ & $\begin{array}{l}\text { Weight } \\
\text { of the } \\
\text { heart } \\
\text { (gm) }\end{array}$ & Diagnosis & No. & Sex & Age & $\begin{array}{l}\text { Blood } \\
\text { pressure }\end{array}$ & $\begin{array}{l}\text { Weight } \\
\text { of the } \\
\text { heart } \\
\text { (gm) }\end{array}$ & Diagnosis \\
\hline 1 & $\mathrm{~F}$ & 30 & $170 / 100$ & 320 & $\begin{array}{l}\text { Aneurysm of basilar } \\
\text { artery, subarachn- } \\
\text { oidal haemorrhage }\end{array}$ & 1. & $\mathbf{F}$ & 33 & $180 / 120$ & 340 & $\begin{array}{l}\text { Chronic glomerulo- } \\
\text { nephritis, uraemia }\end{array}$ \\
\hline \multirow[t]{2}{*}{2} & $\mathrm{~F}$ & 43 & $160 / 100$ & 300 & $\begin{array}{l}\text { Arterial aneurysm, } \\
\text { subarachnoidal }\end{array}$ & 2 & $\mathrm{~F}$ & 49 & $180 / 100$ & 410 & $\begin{array}{l}\text { Chronic pyelonephr- } \\
\text { itis, uraemia }\end{array}$ \\
\hline & $\mathbf{F}$ & 44 & $130 / 80$ & 240 & $\begin{array}{l}\text { haemorrhage } \\
\text { Carcinoma of the } \\
\text { cervix uteri }\end{array}$ & 3 & $\mathrm{~F}$ & 61 & $200 / 100$ & 320 & $\begin{array}{l}\text { Carcinoma of the } \\
\text { breast with meta- } \\
\text { stases, cerebral } \\
\text { haemorrhage }\end{array}$ \\
\hline 4 & $\mathbf{M}$ & 25 & $120 / 80$ & 450 & $\begin{array}{l}\text { Intoxication, } \\
\text { bronchopneumoniae }\end{array}$ & 4 & $\mathrm{~F}$ & 72 & $135 / 70$ & 400 & $\begin{array}{l}\text { Chronic pyelonephr- } \\
\text { itis, uraemia }\end{array}$ \\
\hline 5 & $\mathbf{M}$ & 36 & $180 / 50$ & 610 & $\begin{array}{l}\text { Bicuspid aortic valves, } \\
\text { bronchopneumoniae }\end{array}$ & 5 & $\mathrm{~F}$ & 87 & $270 / 140$ & 480 & $\begin{array}{l}\text { Chronic glomerulo- } \\
\text { nephritis, uraemia }\end{array}$ \\
\hline \multirow[t]{5}{*}{6} & M & 38 & $110 / 90$ & 380 & $\begin{array}{l}\text { Chronic alcoholism, } \\
\text { delirium tremens }\end{array}$ & 6 & $\mathbf{M}$ & 50 & $195 / 110$ & 450 & $\begin{array}{l}\text { Chronic pyelonephr- } \\
\text { itis, uraemia }\end{array}$ \\
\hline & & & & & & 7 & $\mathrm{M}$ & 55 & $210 / 135$ & 450 & $\begin{array}{l}\text { Chronic glomerulo- } \\
\text { nephritis, uraemia }\end{array}$ \\
\hline & & & & & & 8 & $\mathrm{M}$ & 69 & $200 / 140$ & 600 & $\begin{array}{l}\text { Essential hyperten- } \\
\text { sion, cerebral } \\
\text { haemorrhage }\end{array}$ \\
\hline & & & & & & 9 & $\mathbf{M}$ & 69 & $180 / 110$ & 860 & $\begin{array}{l}\text { Chronic glomerulo- } \\
\text { nephritis, uraemia }\end{array}$ \\
\hline & & & & & & 10 & $\mathrm{M}$ & 70 & $210 / 105$ & 550 & $\begin{array}{l}\text { Chronic pyelonephr- } \\
\text { itis, uraemia }\end{array}$ \\
\hline
\end{tabular}

\section{Results}

Oral Mucosa. Capillaries and venules exhibited wall thickening of high degree in 4 of 8 diabetics and of lesser degree in 1 of 11 controls (Table 3).

Table 3. Histopathological grading of the wall thickness in the blood vessels (Capillaries and venules of the oral mucosa and small arteries and arterioles of the oesophagus, stomach, small and large bowels)

\begin{tabular}{llllllll}
\hline Site & Group & \multicolumn{3}{c}{ Histopathogical grading } & Total \\
& & $1+$ & $2+$ & $3+$ & $4+$ & $5+$ & no. \\
\hline \multirow{2}{*}{ Oral } & Diabetics & 1 & 1 & 2 & 2 & 2 & 8 \\
mucosa & Controls I & 6 & & & & & 6 \\
& Controls II & 1 & 3 & 1 & & & 5 \\
Oesophagus & Diabetics & & 2 & 1 & 3 & 3 & 9 \\
& Controls I & 6 & & & & & 6 \\
& Controls II & 1 & 4 & 4 & & & 9 \\
Stomach & Diabetics & 1 & 2 & 6 & 3 & 3 & 15 \\
& Controls I & 6 & & & & & 6 \\
Smal & Controls II & 1 & 5 & 4 & & & 10 \\
bowel & Diabetics & & 2 & 2 & 5 & 3 & 12 \\
& Controls I & 6 & & & & & 6 \\
Large & Controls II & 1 & 5 & 3 & 1 & & 10 \\
bowel & Diabetics & & 3 & 5 & 2 & 3 & 13 \\
& Controls I & 6 & & & & & 6 \\
& Controls II & 1 & 5 & 4 & & & 10
\end{tabular}

The thickened vascular walls were PAS positive and homogeneous and/or laminated (Fig. 1). In van Gieson stained sections they were fuchsinophilic and often included dark hyperchromatic nuclei (pericytes). Wall thickening was accompanied by reduction of the lumen in some parts of the vessel, whereas the lumen in other parts seemed negligibly reduced despite very conspicuous wall thickening. The vascular lesions had a patchy distribution with altered sections of vessel bordering on apparently normal sections. The vessels were sharply demarcated from surrounding tissues. Although the endothelial cells were often prominent and numerous in each vascular section, there was no definite endothelial cell proliferation. The arteriolar walls appeared thickened and were usually strongly PAS positive, but otherwise their structures seemed normal and well preserved. No endothelial cell proliferation could be demonstrated in arteries or arterioles. In some cases the oral mucosa exhibited signs of faint, chronic, unspecific inflammation.

Oesophagus and Gastroïntestinal Tract. Postmortum changes were present in all cases and usually interfered with a detailed scrutiny of the glandular epithelium in the gastrointestinal tract. The gastric mucous glands appeared normal in all cases. The results of the grading 


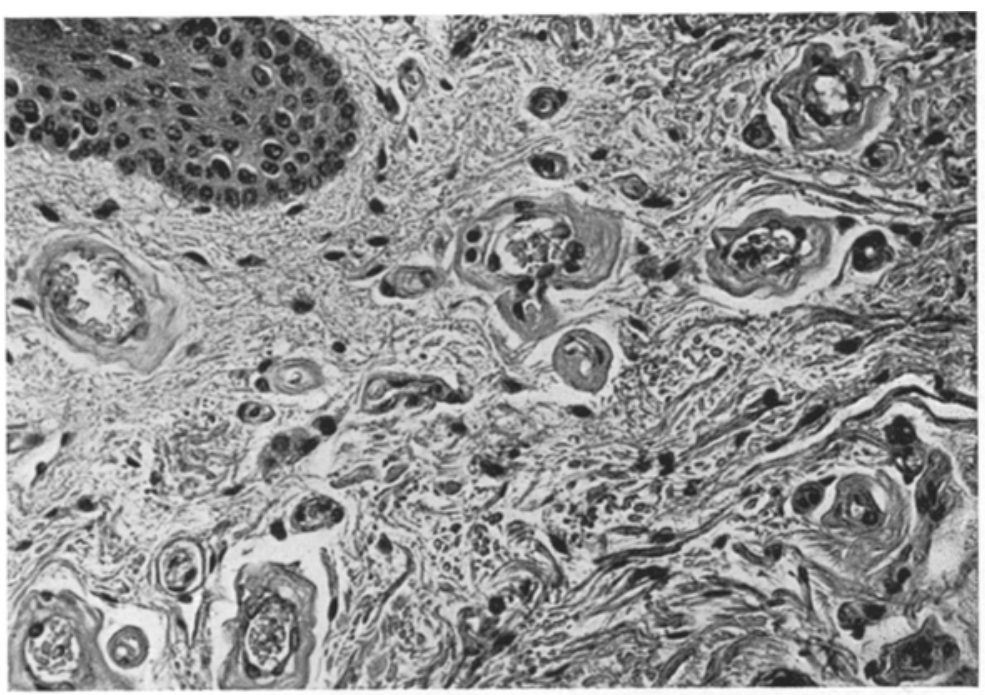

1

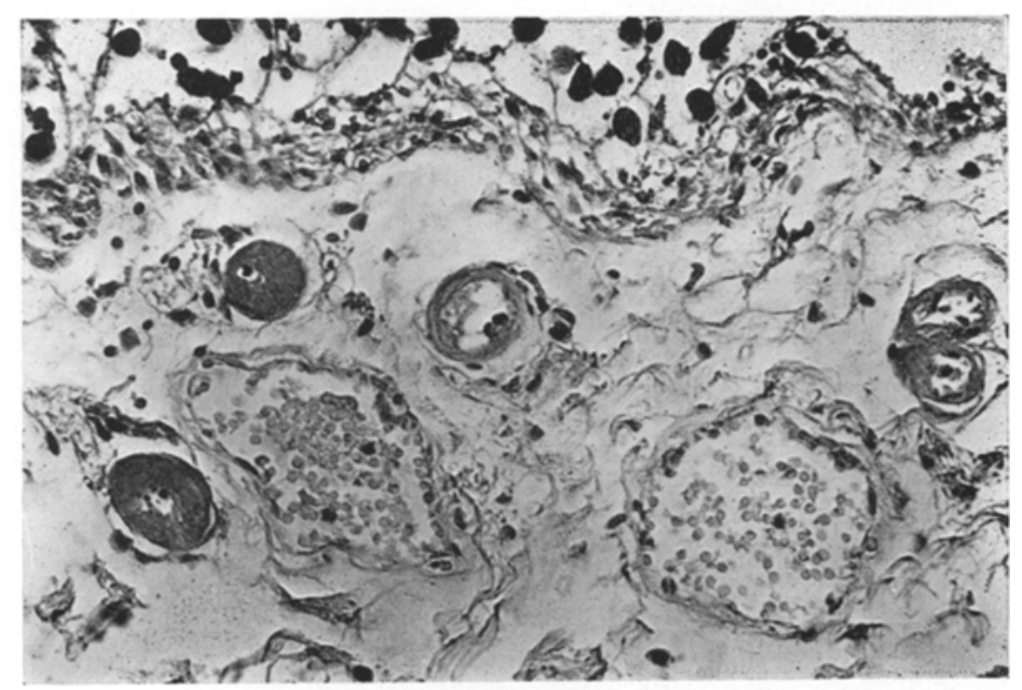

2

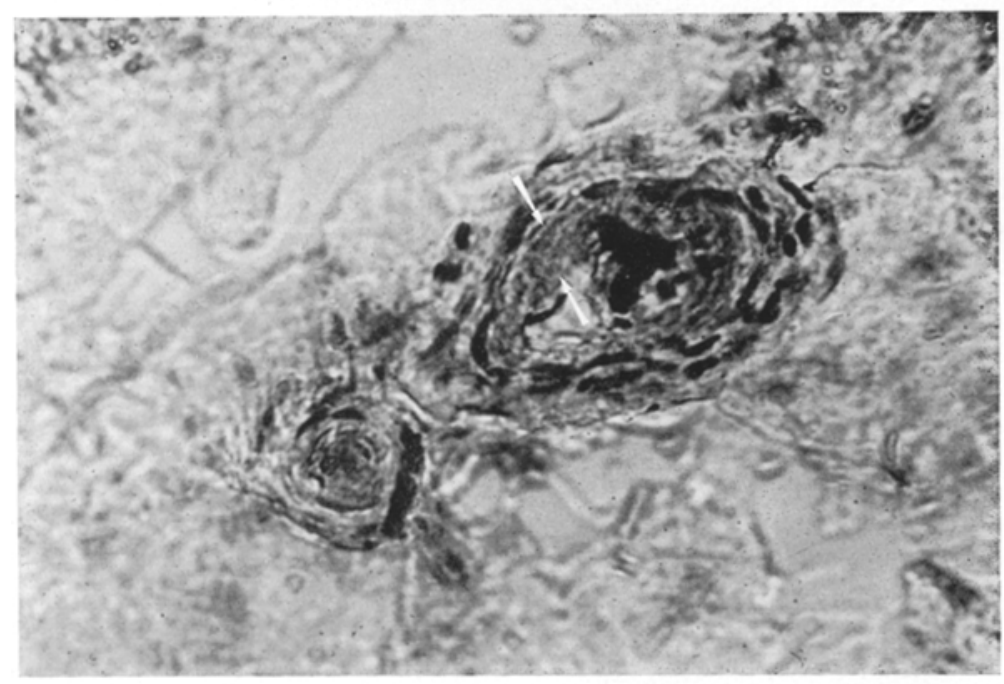

of the arterial and arteriolar lesions (Table 3) in these portions of the digestive tract, show that the diabetics were markedly overrepresented in the higher intervals. The table also reveals that, while no changes were recorded in control group I, hinted or slight changes occurred in control group II. There were no qualitative differences between the various parts of the digestive tract.

Altered arteries and arterioles were observed in the basal portion of the mucosal tunica propria, in muscularis mucosae and in the submucosa. Slightly altered vessels displayed incipient wall thickening and often subendothelial deposits of hyalinized, strongly PAS positive material, which appeared picrinophilic in van Gieson stained sections; otherwise the wall structures were preserved.

In the most gravely altered vessels (Fig 2) it was not possible to distinguish intima, media and adventitia. The markedly thickened vascular wall was hyalinized, and picrinophilic in van Gieson. Thus the wall structures in these vessels had been eradicated and the nuclei in the media had degenerated completely. Sudanophilic material, often uniformly distributed throughout the wall thickness, was consistently demonstrated in vessels with changes of this order (Fig. 3).

The internal elastic coat exhibited changes of varying degree. Often it was intact but sometimes fragmented or completely absent. Occasionally it was incorporated into the thickened wall, dividing it into a more weakly PAS positive inner zone and a more strongly PAS positive outer zone.

The endothelial cells in the gravely altered arteries, if anything, appeared atrophic. Often the arterial lumen was very markedly reduced and not seldom eccentric. The muscularis propria exhibited similar though less pronounced

Fig. 1. Diabetic. Oral mucosa, Capillaries and venules with thickened. PAS-positive, laminated or homogeneous walls with included nuclej (pericytes). McManus PAS. X 260

Fig. 2, Diabetic. Large bowel. Arterioles with strongly PAS-positive, hyalinized, thickened walls. Dilated engorged veins. McManus' PAS. X 260

Fig. 3. Diabetic. Small bowel. Small artery and arteriole with abundant fat (indiated by arrows) in the walls. Scharlach R. X 490 
arterial lesions and capillary wall thickening with increased PAS reactivity.

In all the examined 16 kidneys, 15 pancreases, 13 spleens, in 12 of 15 livers and subcapsularly in 10 of 14 adrenals from diabetics, the same type of grave arterial lesions was demonstrated. In some cases examined the same type of arterial lesion, though less pronounced, was observed in the prostate (5 cases), testes ( 11 cases), pituitary (5 cases) and ovarian hilus (4 cases). Histologically the kidneys in all cases exhibited diffuse and nodular glomeruloselerosis (KIMMELSTIEL-WILSON, 1936). An exudative lesion was found in all the 16 kidneys examined, marked in 11 cases and more moderate in 5 cases.

\section{Discussion}

The present investigation shows that in subjects with diabetes of early onset and long duration and with various causes of death, grave capillary and venular lesions are common in the oral mucosa, and small artery and arteriolar lesions are common within the mucosa and submucosa in the oesophagus, stomach, small and large bowel, including rectum. In the external muscular coat the arterial and capillary lesions were less pronounced.

The capillary and venular lesions were of similar appearance to those described in the skin (GOLDENBERg et al., 1959; Aagenaes and Moe, 1961; AngerVALI and FAGERBERG, 1962; HANDELSMAN et al., 1962) and are characterized by vessel wall thickening, and in general increased PAS-staining and fuchsinophilia, which is assumed to indicate an increased amount of neutral mucopolysacharides and collagen. The dark, hyperchromatic nuclei occurring in the thickened capillary and venular walls are problably pycnotically degenerated pericytes ("mural cells") included in the thickened basement membranes. Some investigators have described endothelial proliferation in capillaries of the skin (HANDELSMAN et al., 1962) and of the lower extremities (GolDENBERG et al., 1959; Pedersen and Olsen, 1962) in diabetics. In the present investigation no such changes were demonstrated in the oral mucosa vessels in the diabetics.

Basement membrane thickening of skin capillaries has been demonstrated electronmicroscopically in diabetics as well as in nondiabetics (BANSON and LACY, 1964). These authors found that in diabetics, hypertension was not necessarily associated with basement membrane thickening, since the basement membranes were significantly thickened in diabetics without hypertension as well.

In the present investigation, the controls with uremia and/or hypertension, in general, had suggested or slight thickening of the capillary and venular walls in the oral mucosa. Thus, it seems justified to conclude that hypertension has not been of major pathogenetic significance in the microangiopathy of the oral mucosa.
The grave arterial lesion demonstrated in the gastroïntestinal tract consists of a hyalin thickening of the vessel walls, which are strongly PAS-positive, picrinophilic and contain abundant fat. The lesion seems to represent a mixture of protein and fat ("fibrinoid"). The endothelial cells were atrophic, and endothelial proliferation as described in small arteries by GoLDENBERG et al. (1959) was not found. Often the muscle cells in the media could not be recognized in the homogenous walls and had apparently degenerated. Similar lesions were also found in arterioles and small arteries of the kidneys, pancreas, liver, spleen, adrenal glands, testes, prostate and ovaries. Such lesions have previously been demonstrated in the kidneys (litt. see DUsTin, 1962), liver (ZsCHOCH, 1963) and pancreas (LAZARUS and VoLK, 1961) especially in elderly diabetics. Zsсносн (1963) showed statistically that both diabetes and hypertension are causal factors in the development of the arterial lesion in the liver, but he pointed out that the lesion is rare in nondiabetics with hypertension. Our study suggests that hypertension has not been of essential importance in the development of the arterial lesions in the diabetics, since the controls with hypertension exhibited only suggested or slight arterial lesions. Moreover, the hypertension in the diabetics was generally slight.

The arterial lesion in the gastrointestinal tract described above is much more severe than that found in biopsy specimens and resectates of the stomach from subjects with varying duration of diabetes (ANGERVALL et al., 1961, 1962). We therefore presume that this grave arterial lesion accentuates terminally in the course of diabetes. Apart from hypertension, terminal complications to the disease may then be of importance. It should be noted that in diabetics more pronounced microangiopathy is observed within ischemic muscular degeneration than in the neighbouring intact muscle tissue (Angervall and Stener, 1965). This possibly implies that ischemia (which is common in the terminal stage of diabetes owing to conditions like renal anemia and/or circulatory insufficiency) accentuates the development of the vascular lesions. The arterial lesion has striking similarities with the glomerular exudative lesion (so called "hyalin-fibrinoid"), which was demonstrated in all our cases, and seems to represent a mixture of various proteins and fat that has leaked out into the capsular space (MUIRHEAD et al., 1956). Thus it strongly resembles the glomerular lesion that appears in animals or humans who have been given large doses of adrenal cortical hormones or ACTH (RICH et al., 1950; BLOODWORTH and HaMwI, 1956; OGILVIE et al., 1965).

Therefore, it is assumed that adrenocortical overactivity is of pathogenetic significance to the gastrointestinal arterial lesion. This assumption is also borne out by the findings of higher corticosteroid levels in complicated diabetes as compared with incomplicated diabetes (Lentue and Thomas, 1964). We believe that the grave arterial lesion in diabetes is, in part, an 
exudative lesion following leakage of various proteins and fat from the blood into arterial walls with a preexisting lesion related to the diabetic condition as such.

\section{References}

Aagenaes, $\varnothing$. , and H. Moe: Light- and electronmicroscopic study of skin capillaries of diabetics. Diabetes 10, $253-259$ (1961).

Alex, M., E.K. Baron, S. Goldennerg and H.T. BluMENTHAL: An autopsy study of cerebrovascular accident in diabetes mellitus. Circulation 25, 663-673 (1962).

Angervall, L., G. Dotevall and K.-E. Lehmann: The gastric mucosa in diabetes mellitus. A functional and histopathological study. Acta med. scand. 169, 339349 (1961).

- - and H. Tillander: Amelioration of diabetes mellitus following gastric resection. Acta med. scand. 160, $743-748$ (1961).

- - S.-E. Fagerberg and K.-E. LehmanN: Gastric mucosa in patients with diabetes of early onset. Acta path. microbiol. scand. suppl. 154, 108-110(1962).

-, and S.-E. FAGERBERG: Skin biopsy in diabetes. Acta path. microbiol. scand. 58, 391-392 (1963).

-, and B. STENER: Tumoriform focal muscular degeneration in two diabetic patients.D iabetologia 1, 39-42 (1965).

-, and J.SÄvE-SöDERBERGH: Diabetisk mikroangiopati i digestionskanalen. Nord. Med. 73, 523 (1965).

Bencosme, S.A., R.O. West, J.W. KerR and D.I. WILson: Diabetic capillary angiopathy in human skeletal muscless. Amer. J. Med. 40, 67-77 (1966).

BANsoN, B.B., and P.E. LACY: Diabetic microangiopathy in human toes. With emphasis on the ultrastructural change in dermal capillaries. Amer. J. Path. 45, 41-58 (1964).

Bloopworth, J.M.B., Jr., and G.J. HAywi : Experimental diabetic glomerulosclerosis. Diabetes 5, 37-43 (1956).

- Diabetic microangiopathy. Diabetes 12, 99-114 (1963).

Blumenthal, H.T., M. Alex and S. Goldengerg: A study of lesions of the intramural coronary artery branches in diabetes mellitus. A.M. A. Arch. Path. 70, $13-28(1960)$.

Bojsen-Møller, F., P. Grønbaek and J. Rostgaard: Light microscopic study of gastrointestinal and skin capillaries in diabetes mellitus. Diabetes 12, 429-432 (1963).

Burstetr, R., S.D. Soule and H.T. Blumenthal: Histogenesis of the pathological processes in placentas of metabolic disease in pregnancy. II. The diabetic state. Amer. J. Obstet. Gynec. 74, 96-104 (1957).

Dagnini, G., and E. Moreschi: L'arteriolopatia del fegato nel diabete mellito. G. Clin. Med. 40, 867-885 (1959).

DUSTIN, P., JR. : Arteriolar hyalinosis. In : International rewiew of experimental pathology. New York. Academie Press, pp. $73-138,1962$.

FAGerderG, S.-E.: Diabetic neuropathy; a clinicl and histological study on the significance of vascular affections. Acta med. scand. suppl. 345, $1-97$ (1959).

FUCHs, U.: Elektronenmikroskopische Untersuchungen menschlicher Muskelcapillaren bei Diabetes mellitus. Frankfurt. Z. Path. 73, 318-328 (1964).

FuNk, H.U.: Veränderungen an kleinen Extremitätengefäßen von Diabetikern. Schweiz. med. Wschr. 95, $487-492$ (1965).
Goldenberg, S., M. Alex, R.A. Joshe and H.T. BuUMENTHAL: Nonatheromatus peripheral vascular disease of the lower extremity in diabetes mellitus. Diabetes 8, $261-273$ (1959).

Handelsman, M.B., T.G. Morrione and B. Ghitman: Skin vascular alterations in diabetes mellitus. Arch. intern. Med. 110, 70-77 (1962).

Houts, G.: Úber elektronenmikroskopische Befunde bei diabetischer Angiopathie. Arch. klin. Chir. 295, 253$258(1960)$.

Krmmelstier, P., and C. Wilson: Intercapillary lesions in the glomeruli of the kidney. Amer..J. Path. 12, 83$98(1936)$.

LAZARUS, S.S., and B.W. VoLK: Pancroas in maturityonset diabetes. A.M.A. Arch. Path. 71, 44-59 (1961).

LeCompte, P.: Glomerular lesions in diabetes: Light microscopy and histochemistry. In Siperstein, M.D., Colwell, A.R., Sr., and K Mayer (editors): Small blood vessel involvement in diabetes mellitus. Washington, D. C., American Institute of Biological Sciences, pp 1-6 and p. 289, 1964.

Lentre, B.C., and J.P. Thomas: Adrenal function and the complications of diabetes mellitus. Lancet 1964 II, $544-549$.

Moore, J.M., and I.D.O. FRew: Peripheral vascular lesions in diabetes mellitus. Brit. med. J. 1965 II, 1923.

Mutrhead, E.E., P.O'B. Montgomery and E. Booth: The glomerular lesions of diabetes mellitus. Arch. intern. Med. 98, 146-161 (1956).

Ogilvie, R.R., M.S. SABoUR and N.W. HoRne: Light and electronmicroscopy of prednisolone-induced nephropathy in rabbits. Diabetes $14,595-605$ (1965).

Pedersme, J., and S. Olsen: Small-vessel disease of the lower extremity in diabetes mellitus. On the patho. genesis of the foot-lesions in diabetics. Acta med. scand. 171, 551-559 (1962).

Pieri, A., P.T. Scarpelit and M. Rizzo: Small blood vessel involvement in diabetes mellitus: Light microscope study of specimens obtained by ear lobe biopsy. Diabetologia 1, $109-115$ (1965).

Rich, A.R., M. Berthrong and I.L. Bennet Jr.: The effect of cortisone upon the experimental cardiovascular and renal lesions produced by anaphylactic hypersensitivity. Bull. Johns Hopk. Hosp: suppl. 87, 549$567(1950)$.

Säve-Söderbergh, J., L. Angervald, S. Eneström and S.-E. FAGERBERG: Morphology and pathogenesis of dermal microangiopathy in young diabetic men. Acta path. microbiol. scand. 66, 274 (1966).

WEBER, H.W., and C.L. WICHT: The peripheral angiopathy of diabetics. A plethysmographic and histopathological study. S. Afr. J. Lab. clin. Med. 8, 83-93 (1962).

WOLTMAN, H.W., and R.M. WrLder: Diabetes mellitus; oathologic changes in spinal cord and peripheral nerves. Arch. intern. Med. 44, 576-603 (1962).

Zacks, S. I., J. J. Pegues and F. A. EiLiot: Interstitial muscle capillaries in patients with diabetes mellitus: A light and electronmicroscope study: Metabolism 11, $381-393$ (1962).

Zsсносп, H.: Arterielle Gefäßveränderungen in der Leber unter besonderer Berücksichtigung des Diabetes mellitus. Verchows Arch. path. Anat. 336, 291-297 (1963),

Lennart Angervali,

JoHANN SÄVE-SöDERBERCH

Pathological Institute. University of Göteborg,

Sahlgredska sjukhuset, Göteborg, Sweden. 